\title{
KONSEP WORLDVIEW: USAHA MELENGKAPI KONSEP STRUKTUR DALAM TEORI STRUKTURASI GIDDENS
}

\section{Johanis Putratama Kamuri}

Sekolah Tinggi Teologi Reformed Injili Internasional

Email: tama.kamuri@gmail.com

\section{Abstrak}

Tulisan ini bertujuan melengkapi konsep struktur dalam teori strukturasi dengan konsep worldview. Teori strukturasi Giddens menekankan struktur sebagai hasil sekaligus medium bagi regularisasi praktik sosial. Namun teori strukturasi menekankan struktur dalam kognisi dan mengabaikan struktur masyarakat. Akibatnya teori ini tidak menjelaskan pertanyaan: bagaimana praktik sosial yang menghasilkan struktur virtual dapat bereksistensi dan teregularisasi dalam masyarakat, sebelum struktur virtual terbentuk dalam kognisi agen? Sebab itu konsep struktur perlu dilengkapi dengan konsep worldview, yang menekankan eksistensi struktur masyarakat yang tampak melalui komponen-komponen kultural. Systematic reviews terhadap tulisan MacIntyre dan dan berbagai tulisan lainnya yang berkaitan dengan konsep worldview menunjukkan bahwa komponen-komponen kultural mengondisikan regularisasi praktik sosial. Hasilnya adalah terbentuknya worldview sebagai medium bagi tindakan sosial. Ini berarti bahwa konsep worldview menekankan korespondensi struktur objektifmasyarakat dan stuktur kognitif. Dengan demikian konsep ini dapat menunjukkan eksistensi struktur masyarakat dan pengaruh komponen-komponen kultural di dalamnya terhadap regularisasi praktik sosial dan pembentukan worldview. Ini adalah jawaban bagi pertanyaan yang tidak dapat diatasi oleh teori strukturasi Giddens.

Kata kunci: Worldview, Struktur, Teori Strukturasi, Komponen-Komponen Kultural.

\section{Abstract}

This paper attempts to enrich the notion of structure within Giddens's structuration theory by introducing the concept of worldview. 
Structuration theory emphasizes structure as a result as well as a medium of the regularization of social practices. It emphasizes structure as forms of cognition while ignores structures as empirical realm. The theory does not explain how social practices that produce cognitive structures exist and taking place continuously in society before they form cognitive structures. Therefore, the concept of structure needs to be complemented with the concept of worldview. The later concept emphasizes the existence of a social structure that reveals itself through cultural components. Reading on MacIntyre's and other related thoughts on worldview, it shows that cultural components produce regularization of social practices. Formation of worldviews mediate patterns of social practices. The worldview concept emphasizes the correspondence of society's objective structure and cognitive structures. This concept addresses the relation of social structure with cultural components in it and the regularization of social practice. The worldview framework provides an answer to the theoretical gap left open in the structuration theory.

Keywords: Worldview, Structure, Structuration Theory, Cultural Components

\section{PENDAHULUAN}

Anthony Giddens adalah sosiolog dengan kontribusi dan pengaruh signifikan-dalam berbagai penelitian sosial, budaya, dan politik hingga saat ini-melalui teori strukturasi. Teori ini bertujuan mengatasi dualisme struktur (objek) dan agen (subjek) dalam ilmu sosial, dengan mengakomodir relasi saling memengaruhi di antara keduanya (Giddens, 1984). Manusia adalah agen historis yang dipengaruhi masyarakat, tetapi bukan produk yang dideterminasi oleh berbagai kekuatan sosial (Giddens, 1979). Posisi agen dan struktur diseimbangkan melalui pengakuan terhadap pengaruh masyarakat terhadap agen dan kemungkinan agen untuk bertindak berbeda dari pengaruh tersebut.

Strukturasi menekankan dualitas struktur dan agen di mana keduanya saling mengandaikan. Tetapi, Giddens tidak menerima eksistensi dan pengaruh struktur objektif di luar agen (Giddens, 1976; 1979). Ia hanya mengakui eksistensi struktur virtual dalam kognisi (struktur kognitif). Bagi Giddens (1979; 1984), struktur 
virtual adalah skema kognitif yang terbentuk melalui regularisasi praktik sosial dalam masyarakat yang dihidupi agen. Struktur virtual adalah medium bagi praktik sosial, karena menjadi paradigma bagi pemikiran, interpretasi, dan tindakan. Karena berperan sebagai paradigma berpikir dan bertindak, skema kognitif ini memungkinkan sekaligus membatasi tindakan dalam sistem nilai masyarakat yang dihidupi agen. Jadi, struktur virtual mengondisikan tindakan. Meskipun demikian, Giddens juga menekankan kapasitas (power) agen untuk bertindak berbeda (Giddens, 1979).

Struktur bersifat subjektif, karena hanya bereksistensi dalam kognisi. Tidak ada struktur objektif yang memengaruhi tindakan agen secara langsung. Pengaruh masyarakat dimediasi oleh struktur virtual sehingga tindakan agen hanya merepresentasikan struktur virtual (Giddens, 1979). Namun konsep struktur ini memiliki kelemahan. Jika struktur kognitif terbentuk melalui regularisasi praktik sosial, maka harus diandaikan bahwa eksistensi praktik sosial mendahului eksistensi struktur virtual dalam kognisi. Bagaimana praktik sosial, yang membentuk struktur kognitif, dapat bereksistensi dan tergularisasi dalam masyarakat, sebelum struktur kognitif terbentuk dalam diri agen? Pertanyaan ini mempersoalkan asal-usul praktik sosial pembentuk struktur virtual, yang telah teregularisasi dalam kehidupan sosial, sebelum struktur tersebut terbentuk dalam kognisi anggota masyarakat.

Tulisan ini menunjukkan bahwa konsep struktur dalam pemikiran Giddens tidak menjawab persoalan penelitian tersebut, sehingga perlu dilengkapi dengan ide tentang struktur kognitif yang memiliki korespondensi dengan struktur masyarakat. Tulisan ini juga menunjukkan bahwa persoalan penelitian terjawab jika ada pengakuan terhadap eksistensi struktur objektif dan pengaruhnya terhadap regularisasi praktik sosial, melalui sejumlah komponen kultural. Komponen-komponen tersebut memengaruhi tindakan secara langsung dan tidak langsung (melalui pembentukan struktur virtual dalam kognisi). Penjelasan diberikan melalui konsep worldview, yang dibentuk dari pemikiran Giddens tentang struktur 
virtual dan ide Alasdair MacIntyre tentang skema normatif dan konstitutif dalam kognisi agen-agen, yang menghidupi kebudayaan yang sama. Skema tersebut terbentuk dalam konteks tradisi komunitas, yang dihidupi agen dan yang memengaruhi pemikiran dan tindakan (MacIntyre, 2006).

Pemikiran MacIntyre tentang struktur paradigmatik penentu cara pikir dan tindakan-yang dalam tulisan ini disebut worldviewmemiliki keserupaan dengan pemikiran Giddens tentang struktur virtual. Tetapi, MacIntyre berbeda dari Giddens dalam menekankan berbagai komponen kultural yang mengondisikan praktik sosial secara langsung maupun tidak langsung, melalui pembentukan struktur kognitif. Komponen kultural yang dimaksud antara lain: pertama, practice, aktivitas sosial-kooperatif yang dianggap mengandung nilai-nilai internal penentu keutamaan. Melalui aktivitas sosial-kooperatif, agen mewujudkan nilai-nilai tersebut dan menjadi manusia ideal dalam pandangan masyarakat (MacIntyre, 1984). Kedua, tradisi moral komunitas yakni nilai-nilai terberi yang menjadi standar bagi pemahaman terhadap realitas dan praktik sosial (MacIntyre, 1984). Ketiga, tatanan narasi individual yakni berbagai pengalaman hidup yang dimaknai berdasarkan dua komponen pertama dan yang memengaruhi pemahaman agen terhadap realitas dan tindakan (MacIntyre, 1984).

Tiga komponen ini menjadi petunjuk pada eksistensi struktur masyarakat, yang membentuk regularisasi praktik sosial dan struktur paradigmatik dalam kognisi anggotanya. Pemikiran ini melengkapi keterbatasan penjelasan Giddens yang menolak struktur eksternal dan pengaruhnya terhadap agen. Sebaliknya pemikiran Giddens juga melengkapi MacIntyre, yang tidak menjelaskan bagaimana struktur paradigmatik mempengaruhi pemikiran dan tindakan agen.

Harus diakui bahwa Pierre Bourdieu telah menjelaskan relasi agen dan struktur dengan menekankan pengaruh struktur objektif terhadap pembentukan struktur kognitif dan tindakan. Ia mengandaikan berbagai wilayah kehidupan sosial sebagai arena 
(fields) yang diatur oleh doksa (doxa), yakni aturan, nilai, konvensi, yang disajikan sebagai akal sehat (Bourdieu, 1996). Doksa mengandaikan struktur sosial pembentuk praktik sosial, yang dapat dibandingkan dengan prinsip-prinsip kultural, yang disuarakan tiga komponen kultural dalam pemikiran MacIntyre. Melalui internalisasi, perangkat aturan struktur sosial tersebut membentuk habitus, yakni struktur kognitif yang mengarahkan pemahaman dan tindakan, yang bersesuaian dengan aturan-aturan struktur sosial (Bourdieu, 1984). Ini berarti habitus adalah konsep yang serupa dengan struktur vitual. Namun, Bourdieu tidak menunjukkan bagaimana struktur objektif dapat memengaruhi pembentukan struktur kognitif dan tindakan agen. Konsep worldview dapat mengatasi keterbatasan ini dengan menekankan korespondensi struktur kognitif dengan struktur masyarakat.

Konsep worldview mengakui pengaruh struktur objektif terhadap regularisasi praktik sosial dan pembentukan struktur kognitif, serta pengaruh struktur kognitif terhadap pemikiran dan praktik sosial. Hal ini serupa dengan pemikiran Alfred Schutz bahwa keseharian masyarakat (lifeworld) didasarkan pada tindakan (wirken), yang diarahkan oleh pengetahuan bersama, sebagai paradigma atau appresentative structures dalam kesadaran agen (Schutz dalam Kassab, 1991). Giddens (1984) mengadopsi pemikiran Schutz dan mengaitkannya pada konsep kesadaran praktis atau skema pengetahuan, yang berkaitan erat dengan struktur virtual. Persoalannya, Schutz tidak mengulas objektifitas struktur sosial, proses pembentukan, dan komponen-komponen kultural pembentuk struktur, yang diandaikan dalam pemikirannya. Keterbatasan tersebut akan dilengkapi melalui konsep worldview.

Keseimbangan penjelasan diberikan Peter Berger melalui sosiologi pengetahuan yang menekankan konsep realitas dan pengetahuan (Berger \& Luckmann, 1991). Dua konsep tersebut mengakui eksistensi masyarakat, sebagai struktur objektif, yang dibentuk untuk menghasilkan keteraturan melalui proses institusionalisasi dan legitimasi. Selanjutnya, melalui sosialisasi, 
masyarakat terinternalisasi di dalam kognisi sebagai pengetahuan bersama, yang memengaruhi kesadaran dan tindakan individu. Namun, Berger tidak menunjukkan komponen-komponen yang menjadi sarana sosialisasi, yang bermuara pada pembentukan struktur sosial dan struktur kognitif. Konsep worldview menekankan hal yang sama dengan Berger, sekaligus menunjukkan berbagai komponen kultural yang menjadi sarana sosialisasi dan berperan dalam pembentukan worldview, sebagai pengetahuan bersama.

Sifat teoritis membedakan tulisan ini dari tulisan-tulisan sebelumnya, yang menggunakan pemikiran Giddens untuk tujuan praktis, antara lain: Dixon (2011), yang menggunakan konsep dualitas struktur untuk memahami perilaku penggemar sepak bola. Konsep yang sama digunakan Thoyyibah (2015) untuk memahami korupsi, kejahatan struktural yang dilakukan agen dengan memanfaatkan struktur mikro dan makro. Sementara itu, Kamuri (2021) menggunakan konsep struktur untuk memahami kekuatan dan perubahan pada masyarakat tradisional. Di Afrika Selatan, van Rooyen (2013) menggunakan strukturasi untuk memperoleh pemahaman terhadap kompleksitas interaksi struktur terjemahan dengan penerjemah dan kontribusinya bagi pengaruh globalisasi di Afrika Selatan.

Sumber data utama bagi tulisan ini adalah literatur yang berkaitan dengan pemikiran Giddens dan MacIntyre tentang struktur, maupun dengan konsep worldview. Literatur tersebut didekati dengan systematic reviews (Denscombe, 2014), yang menekankan beberapa langkah utama: pertama, review literatur untuk mengidentifikasi permasalahan penelitian, sebagaimana dipaparkan pada bagian sebelumnya. Kedua, review literatur untuk memberi penjelasan terbaik terhadap permasalahan. Hal ini diawali dengan review literatur untuk memahami konsep struktur dalam strukturasi. Selanjutnya adalah review terhadap literatur yang berfungsi melengkapi konsep struktur dan membentuk konsep worldview. Sebab itu, tulisan ini menganalisis konsep struktur dalam strukturasi; menganalisis komponen-komponen kultural, yang mengandaikan eksistensi struktur objektif pembentuk worldview 
dan penentu cara pikir maupun praktik sosial (dengan memanfaatkan pemikiran Giddens); dan menjelaskan konsep worldview, yang menjadi titik temu struktur masyarakat dan struktur kognitif.

\section{STRUKTUR OBJEKTIF, STRUKTUR KOGNITIF, DAN REGULARISASI PRAKTIK SOSIAL}

Bagian ini mengatasi keterbatasan dalam teori strukturasi, dengan menekankan eksistensi struktur objektif, struktur kognitif, dan pengaruhnya terhadap tindakan. Giddens menekankan relasi tak terpisahkan antara struktur dan tindakan agen. Baginya, struktur kognitif, yang terbentuk dari regularisasi praktik sosial, memengaruhi regularisasi maupun transformasi (deregularisasi) praktik sosial. Kehidupan orang Sumba penganut Marapu adalah contohnya. Anak-anak orang Sumba tidak dilahirkan dengan struktur kognitif. Tetapi, keterlibatan secara reguler dalam praktik sosial, berdasarkan prinsip-prinsip adat, membentuk pengetahuan bersama (struktur kognitif) dalam kognisi anak-anak orang Sumba. Akibatnya, mereka dapat memahami dan menghidupi tradisi tanpa bergantung pada tuntutan orang lain. Tetapi, setelah memperoleh pendidikan dan mengenal prinsip-prinsip yang berbeda dari Marapu, sebagian dari anak-anak orang Sumba mengalami perubahan cara pikir (struktur kognitif). Mereka menerima dan menghidupi prinsip-prinsip Kristen dan ilmu pengetahuan, yang dianggap lebih maju, dan menjadi kritis terhadap Marapu. Perubahan struktur kognitif membuat sebagian orang Sumba hanya menghidupi tradisi, yang dianggap tidak bertentangan dengan prinsip-prinsip yang lebih maju.

Namun, Giddens menolak eksistensi dan peran struktur objektif. Beberapa kritik dapat diberikan kepada pemikiran ini. Pertama, Giddens tidak menjelaskan apa yang memungkinkan regularisasi praktik sosial, sebelum struktur kognitif terbentuk dan bagaimana hal itu terjadi. Bayi tidak dilahirkan dengan struktur kognitif sebagai paradigma berpikir. Struktur kognitif terbentuk setelah ia melibatkan diri atau dilibatkan dalam praktik sosial. Perlu 
penjelasan tentang apa yang memungkinkan sang bayi terlibat dalam regularisasi dan bagaimana itu terjadi. Kedua, penolakan terhadap struktur masyarakat tidak memberi penjelasan memuaskan terhadap fakta pengaruh kebudayaan terhadap tindakan agen, termasuk praktik sosial teregularisasi.

Pengakuan terhadap struktur masyarakat, yang objektif, adalah kunci untuk menjelaskan pengaruh masyarakat terhadap tindakan agen dan menjawab pertanyaan bagaimana pengaruh tersebut terjadi, sebagaimana ditegaskan dalam kritik pertama. Sebab itu, penelitian ini memanfaatkan pemikiran MacIntyre tentang peran berbagai komponen kultural-yang mengandaikan eksistensi struktur masyarakat-untuk melengkapi konsep struktur dalam perspektif Giddens.

Manusia bertahan hidup dengan membentuk masyarakat dan mempertahankan stabilitasnya, melalui penentuan peran masingmasing anggotanya (Berger \& Luckmann, 1991). Masyarakat pemburu, misalnya, berusaha mencapai kestabilan dengan menemukan serta mempertahankan pola berburu, peralatan terbaik, dan peran setiap pemburu, yang menjamin hasil maksimal. Pola tersebut menjadi stok pengetahuan bersama yang dipertahankan melalui regularisasi demi kestabilan sosial dan keberlangsungan masyarakat. Pengetahuan bersama dijustifikasi dan dilegitimasi sehingga dapat diteruskan kepada generasi selanjutnya. Ini membuat pengetahuan bersama dimiliki setiap generasi dalam masyarakat tersebut.

Pengulangan, justifikasi, dan legitimasi praktik sosial memiliki kaitan dengan struktur masyarakat (objektif). Struktur adalah skema abstrak, yang terbentuk dari sejumlah komponen yang saling berkaitan dalam sistem tertentu (Hoed, 2014). Sebab itu istilah struktur masyarakat dalam tulisan ini mengacu pada fakta bahwa masyarakat memiliki struktur pembentuk regularitas hidup dan perilaku agen-agen yang ada di dalamnya. Struktur tersebut bersifat abstrak sehingga tidak terobservasi secara langsung. Meskipun demikian, komponen-komponen pembentuk struktur dapat diidentifikasi dan diamati, untuk memahami struktur 
masyarakat. Praktik seperti inilah yang dilakukan kaum strukturalis seperti Levi Straus, yang menganalisa sistem kekerabatan dan mitos untuk memahami struktur masyarakat.

Berbagai komponen pembentuk struktur, yang dapat disebut komponen kultural, berfungsi mempertahankan regularisasi praktik sosial terjustifikasi dan terlegitimasi, karena praktik tersebut menjamin kestabilan dan kelangsungan hidup masyarakat. Komponen kultural pertama adalah tradisi moral komunitas, yang mengatur peran (role) anggota masyarakat melalui aturan-aturan (rules), yang dikonstruksi berdasarkan pengalaman kolektif-historis dan sejumlah keyakinan masyarakat (MacIntyre, 1984). Tradisi moral mengandung prinsip-prinsip, yang berfungsi sebagai standar pemahaman terhadap realitas maupun panduan bagi tindakan (Kamuri \& Pratama, 2018). Tradisi moral dikonstruksi significant others (pemimpin, yang diakui otoritasnya oleh masyarakat) untuk mempertahankan stabilitas sosial. Prinsip-prinsip tersebut disosialisasi kepada setiap generasi-melalui narasi imanjiner, seperti mitos, atau narasi historis (MacIntyre, 1984)-untuk membentuk komitmen dan ketaatan pada tradisi komunitas.

Tradisi moral dikonstruksi berdasarkan keyakinan dan pengalaman kolektif-historis masyarakat. Sebab itu, tradisi moral dapat berfungsi sebagai narasi otoritatif, yang memengaruhi regularisasi tindakan melalui dua kekuatan psikologis. Pertama, kekuatan psikologis yang membentuk identitas yang sama melalui praktik sosial yang sama. Kedua, kekuatan psikologis yang menjamin rasa aman ontologis. Rasa aman ontologis adalah rasa aman yang diperoleh karena adanya jaminan perlindungan dari ancaman dan bahaya (Kinnvall, Manners, \& Mitzen, 2018), sehingga masyarakat memahami dan menerima kondisi sosialnya sebagai "apa yang seharusnya." Tradisi moral menjadi narasi otoritatif, yang memengaruhi regularisasi praktik sosial, karena menjamin rasa aman ontologis dan mengondisikan kesamaan identitas agenagen yang menghidupi komunitas yang sama (melalui praktik sosial yang sama). 
Fungsi ini dapat ditemukan dalam mitos, tradisi, dan ritual serta pemaknaannya maupun ajaran-ajaran agama berdasarkan kitab sucinya. Contoh konkritnya adalah peran prinsip-prinsip agama Marapu dalam menstrukturkan kehidupan penduduk asli Pulau Sumba. Salah satu komponen budaya yang memungkinkan situasi ini adalah mitos, yang mengekspresikan keyakinan orang Sumba bahwa adat diturunkan leluhur berdasarkan persetujuan Tuhan, sehingga ketaatan menjamin keharmonisan kosmik dan membebaskan dari bencana, sedangkan ketidaktaatan mengakibatkan malapetaka (Kamuri, 2020). Situasi ini mengondisikan ketaatan terhadap prinsip-prinsip Marapu, yang tampak melalui regularisasi praktik sosial berdasarkan prinsipprinsip tersebut. Regularisasi prinsip Marapu dalam keseharian membentuk keserupaan identitas orang Sumba di seluruh Sumba.

Efektifitas tradisi moral sebagai narasi otoritatif dikondisikan oleh pemaknaan dan otoritas yang diberikan padanya oleh masyarakat. Dalam kasus orang Sumba, mitos menjadi tradisi moral yang berotoritas membentuk regularisiasi praktik sosial karena dilekatkan pada otoritas Tuhan, leluhur yang sangat dihormati, dan significant others (tua adat, orangtua atau pemimpin yang berotoritas) yang mensosialisasikannya. Selain itu prinsip-prinsip mitologis diyakini efektif menjamin kesejahteraan masyarat.

Komponen kultural kedua adalah practice, aktivitas sosial yang dianggap mengandung nilai-nilai yang sangat penting dan berguna bagi masyarakat, sehingga agen yang terlibat dalam aktualisasinya dianggap telah mencapai keutamaan (MacIntyre, 1984). Practice merupakan aktivitas sosial yang dikaitkan pada tujuan bersama dan berbagai keutamaan. Peran setiap agen dan aturan-aturan dalam aktivitas tersebut diatur dengan narasi otoritatif dan prinsip-prinsip masyarakat yang menjadikannya sebagai kegiatan bermakna bagi pelaku maupun masyarakat.

Makna bagi kehidupan individu dan masyarakat diperoleh ketika aktivitas tersebut berlangsung sebagaimana seharusnya dan mencapai tujuannya-tujuannya (Magnis-Suseno, 2000). Ini berarti practice menjamin key life experiences, pengalaman kunci dan 
bermakna yang diperoleh di dalam dan melalui aktivitas bersama anggota masyarakat lain. Pengalaman ini bermakna karena beberapa alasan: pertama, melalui aktivitas tersebut pelaku menemukan bahwa dirinya berguna dan berkualitas berdasarkan deskripsi tradisi dan narasi otoritatif. Kedua, pelaku memperoleh pengakuan, penerimaan, dan penghargaan dari masyarakat yang menghidupi tradisi dan narasi otoritatif yang sama.

Pengalaman ini juga bisa disebut pengalaman kunci bagi pelaku maupun masyarakat, karena mempersiapkan pelaku dan mendorong anggota masyarakat lain untuk terlibat dalam aktivitas serupa dan, dengan demikian, memungkinkan regularisasinya. Hal ini dapat dibandingkan dengan key life experiences yang diperoleh para tentara yang memenangkan perang bagi bangsanya. Rasa bangga, berharga, dan berguna dalam dirinya berkorespondensi dengan penghargaan dan penerimaan, yang diberi masyarakat melalui gelar pahlawan. Pengalaman ini mempersiapkan sang tentara untuk masuk ke dalam tugas selanjutnya sekaligus memupuk nasionalisme dan mendorong anggota masyarakat lain untuk memperjuangkan kepentingan bangsa.

Key life experiences yang diperoleh melalui practice-yang ditentukan dan dimaknai masyarakat-mengondisikan ketaatan anggota masyarakat pada narasi otoritatif dan prinsip-prinsip komunitas. Key life experiences juga mendorong keterlibatan anggota masyarakat dalam berbagai aktivitas sosial, karena pengalaman ini hanya diperoleh dengan masuk ke dalam tradisi yang dihidupi bersama anggota masyarakat lain. Practice dan key life experiences menstrukturkan kepatuhan dan membentuk cara pikir.

Penjelasan ini menunjukkan bahwa prinsip-prinsip dalam tradisi moral menawarkan kesamaan identitas pengikat masyakat dan rasa aman ontologis. Sementara itu, practice menawarkan key life experience yang bermakna bagi individu maupun komunitas. Melalui hal-hal yang ditawarkannya, dua komponen tersebut mengondisikan kepatuhan dan kecenderungan meregularisasi praktik sosial yang disarankan. Dua komponen tersebut dapat dipahami-dalam perspektif Berger dan Luckmann (1991)-sebagai 
sarana sosialisasi prinsip-prinsip komunitas. Kedua komponen ini memengaruhi regularisasi praktik sosial secara langsung, tanpa dimediasi oleh struktur kognitif.

Komponen kultural ketiga adalah penghayatan dan pemaknaan subjektif agen terhadap pengalaman individualnya. Manusia memiliki perbedaan pengalaman individual dalam seluruh dimensi hidup sejak kelahiran sampai kematian. Pemaknaan terhadap berbagai pengalaman tersebut membentuk hidup dan historisitas agen (MacIntyre, 1984). Ini berarti pemaknaan subjektif ikut menentukan tindakan-tindakan agen. Pertanyaannya adalah apa yang menjadi standar pemaknaan terhadap pengalaman individual? Narasi otoritatif dan keserupaan key life experiences tidak menyeragamkan pengalaman individual. Namun, pemaknaan terhadap realitas dan pengalaman individual didasarkan pada prinsip-prinsip komunitas yang disuarakan melalui narasi otoritatif (MacIntyre, 1984) dan didukung oleh key life experiences.

Interpretasi terhadap realitas, termasuk pengalaman individual, dikondisikan oleh prinsip-prinsip yang bersumber dari komponen-komponen kultural. Sebab itu MacIntyre (2006) menegaskan bahwa agen-agen yang menghidupi kebudayaan yang sama memiliki skema normatif dan konstitutif yang sama bagi pemikiran dan tindakan mereka. Ini merujuk pada kesamaan struktur sosial dan sistem nilai, yang disosialisasi melalui komponen-komponen kultural, maupun kesamaan struktur kognitif, yang menstrukturkan pemikiran dan praktik sosial.

Komponen-komponen kultural adalah sarana sosialisasi prinsip-prinsip komunitas. Melaluinya, struktur objektif memengaruhi regularisasi praktik sosial secara langsung. Pemikiran ini memiliki beberapa implikasi. Pertama, penolakan Giddens terhadap eksistensi dan pengaruh struktur objektif harus ditolak. Struktur objektif menyatakan eksistensi melalui komponenkomponen kultural. Kedua, struktur objektif memberi pengaruh langsung terhadap regularisasi tindakan dan stabilitas masyarakat melalui komponen-komponen kultural. Ini melampaui pemikiran 
Giddens, yang tidak memungkinkan pengaruh langsung masyarakat terhadap tindakan. Pengaruh masyarakat, menurut Giddens, harus dimediasi oleh struktur kognitif yang terbentuk dari regularisasi praktik sosial.

Penjelasan di atas menunjukkan bahwa, melalui komponenkomponen kultural, masyarakat memengaruhi regularisasi praktik sosial secara langsung (dengan langsung mengarahkannya pada praktik sosial tertentu). Mitos orang Sumba, misalnya, menentukan cara hidup yang dikehendaki Tuhan dan leluhur. Cara hidup ini disosialisasi significant others kepada seluruh anggota komunitas, dengan keyakinan bahwa ketaatan mendatangkan kesejahteraan. Karena dikaitkan pada otoritas Tuhan, leluhur, dan kesejahteraan, orang Sumba cenderung meregularisasi cara hidup yang diajarkan melalui mitos. Pengaruh langsung struktur objektif terhadap tindakan menjelaskan asal-usul regularisasi praktik sosial, yang tidak dapat dijelaskan melalui konsep Giddens tentang struktur.

Berbagai komponen kultual juga memungkinkan pengaruh tidak langsung masyarakat, terhadap praktik sosial, melalui pembentukan struktur kognitif. Keterlibatan dalam permainan dan sosialisasi prinsip-prinsip sepak bola menghasilkan skema aturanaturan sepak bola dalam kognisi. Ini memungkinkan para pemain memahami instruksi pelatih atau tindakan wasit, yang menunjuk titik putih. Fakta ini dapat dijelaskan melalui penjelasan Giddens (1979; 1984) dan MacIntyre (2006) bahwa praktik sosial dipengaruhi struktur kognitif. Struktur kognitif, yang mengondisikan regularisasi praktik sosial, terbentuk dari regularisasi praktik sosial. Regularisasi praktik sosial (penghasil struktur kognitif) dipengaruhi struktur masyarakat. Artinya, struktur objektif akan direprestasikan juga oleh setiap praktik sosial, yang dikondisikan oleh struktur kognitif. Ini adalah pengaruh tidak langsung dari struktur objektif terhadap regularisasi praktik sosial.

Pengaruh tidak langsung struktur objektif terhadap tindakan dapat dijelaskan melalui pemikiran Giddens tentang pengaruh struktur kognitif terhadap praktik sosial. Berbagai komponen kultural menghasilkan regularisasi praktik sosial, yang kemudian- 
sebagaimana ditegaskan Giddens-menghasilkan struktur kognitif. Struktur kognitif menjadi medium bagi praktik sosial karena perannya sebagai skema aturan (rules) dan sumber daya (resources), properti dari sistem sosial masyarakat pembentuk struktur tersebut (Giddens, 1979).

Penjelasan di atas memiliki beberapa implikasi yang menegaskan pengaruh tidak langsung dari struktur objektif terhadap struktur kognitif. Pertama, struktur kognitif bersifat virtual, kultural, dan paradigmatik. Struktur bersifat virtual, karena terbentuk dalam kognisi agen. Struktur bersifat kultural, karena aturan dan sumberdaya merupakan properti struktural pembawa ciri masyarakat pembentuknya. Sifat paradigmatik berkaitan dengan peran struktur sebagai paradigma atau skema yang diacu dalam praktik sosial. Kedua, karena berfungsi sebagai paradigma berpikir dan bertindak, struktur membatasi praktik sosial sesuai skema aturan dan sumberdaya yang ada padanya. Selanjutnya aturan dan sumberdaya adalah properti kultural masyarakat penghasil, maka praktik sosial yang dihasilkan tidak dapat tidak berada dalam batas-batas kultural masyarakat. Dengan demikian struktur juga menjadi medium bagi kontinuitas tindakan dengan kebudayaan. Ketiga, karena paradigma bagi praktik sosial bereksistensi dalam kognisi, maka anggota masyarakat merupakan agen berpengetahuan. Masyarakat senantiasa menunjukkan sifatsifat struktural melalui praktik sosial teregularisasi, yang menegaskan bahwa mereka adalah agen berpengetahuan (Giddens, 1984). Ini tidak hanya berarti bahwa tindakan masyarakat merepresentasikan struktur paradigmatik dalam kognisi. Ini juga berarti bahwa struktur paradigmatik merupakan pengetahuan bersama, yang menentukan cara pikir dan tindakan.

Pengetahuan bersama merupakan kesadaran praktis, keahlian bersosial tak sadar (tacit knowledge) berdasarkan gugus pengetahuan yang diandaikan begitu saja (taken for granted knowledge) dan berfungsi sebagai aturan-aturan bagi tindakan (Thoyyibah, 2015). Pengetahuan ini berada di bawah sadar sehingga agen memiliki keahlian atau kemampuan untuk menjawab semua pertanyaan 
esensial dan kondisi yang dihadapinya secara spontan (Shani, 2017). Struktur kognitif memberi pengetahuan dan keahlian untuk bertindak dalam situasi konkret. Agen terorientasi pada struktur sehingga secara spontan menerapkan pengetahuannya dalam praktik sosial tanpa harus merencanakan tujuan tertentu atau tanpa mempertanyakan hasil-hasilnya. Dalam situasi ini struktur kognitif memungkinkan tindakan yang tersituasi secara kultural.

Meski demikian, struktur kognitif juga memungkinkan deregularisasi praktik sosial, melalui tindakan agen yang berbeda dari masyarakatnya, bahkan dapat mengubah struktur objektif. Hal ini dapat dikaitkan pada beberapa hal. Pertama, agen memiliki otonomi relatif untuk bertindak berbeda dengan memanfaatkan sumberdaya sebagai bagian dari komponen struktur kognitif (Giddens, 1979). Otonomi ini relatif karena menegaskan kemampuan bertindak berbeda, yang masih ada dalam batas-batas struktural. Batas tersebut adalah sumberdaya sebagai komponen struktural. Otonomi juga relatif karena agen dibatasi oleh otonomi agen lain. Dalam relasi sosial, agen dapat saling memengaruhi untuk tujuan masing-masing. Kedua, agen memiliki kuasa (power) sebagai kapasitas transformatif yang dapat digunakan untuk memanfaatkan otonomi relatifnya demi tercapainya tujuan tertentu dan bermuara pada transformasi praktik sosial. Menurut Giddens (1979) sumberdaya adalah medium yang memungkinkan pemanfaatan kapasitas transformatif untuk menghasilkan perubahan sebab transformasi melibatkan mobilisasi sumberdaya untuk memengaruhi orang lain. Struktur kognitif berperan dalam transformasi karena agen harus memanfaatkan berbagai komponen struktur untuk memengaruhi agen lain demi tujuan tersebut.

Ketiga, agen memiliki kesadaran diskursif. Sementara kesadaran praktis adalah tacit knowledge, kesadaran diskursif adalah kemampuan mengartikulasikan pengetahuan dalam kata-kata (Giddens, 1984). Kesadaran diskursif mempresaposisikan kemampuan menyadari dan menjelaskan pengetahuan yang dimiliki serta memberi alasan bagi tindakan. Ini merupakan kapasitas reflektif atau kemampuan mengambil jarak dan 
memonitor tindakan sendiri, tindakan agen lain dan aspek-aspek sosial maupun material untuk menentukan tindakan yang tepat (Giddens, 1984). Pavaler, musyawarah masyarakat Afrika subSahara untuk menjawab tantangan kontemporer terhadap tradisi, adalah contohnya. Tantangan, umumnya, dijawab dengan merujuk pada tradisi leluhur. Namun, tantangan yang tidak terjawab berdasarkan prinsip-prinsip leluhur dapat diinterpretasi dan dijawab (dalam pavaler) dengan pendekatan baru (Magnis-Suseno, 1992). Dalam menghadapi tantangan, agen dapat mengambil jarak dari tradisi, memikirkan ulang prinsip-prinsip komunitas, dan memberi interpretasi yang memungkinkan perubahan (meskipun masih terjadi dalam batas-batas kultural). Keputusan dijelaskan, kepada masyarakat, untuk dihidupi secara bersama-sama. Ini berarti refleksi memungkinkan pemanfaatan kapasitas transformatif untuk memobilisasi sumberdaya, dengan tujuan memengaruhi agen. Melaluinya, agen menghasilkan derutinisasi praktik sosial (perubahan).

Derutinisasi membuat struktur yang sebelumnya berfungsi sebagai paradigma bagi praktik sosial tidak lagi relevan. Derutinisasi menghasilkan praktik sosial baru yang regularisasinya memengaruhi pembentukan struktur kognitif baru, yang berbalik mengondisikan perilaku agen. Agen memanfaatkan kapasitas trasformatif dan unsur-unsur struktural untuk mencapai perubahan. Perubahan tersebut memengaruhi pembentukan struktur baru yang berperan sebagai medium tindakan sosial sehingga perubahan dikekalkan melalui rutinisasi.

Tindakan atau praktik sosial memiliki kaitan dengan dua macam struktur yakni struktur objektif, yang mengondisikan tindakan secara langsung, dan struktur kognitif, yang melaluinya masyarakat memengaruhi regularisasi praktik sosial secara tidak langsung. Dua struktur tersebut berkaitan, sehingga struktur kognitif menghasilkan tindakan yang bersesuaian dengan prinsipprinsip struktur objektif. Meski demikian, struktur kognitif juga menghasilkan tindakan yang berbeda dari struktur objektif, bahkan yang dapat menghasilkan transformasi struktur objektif. 


\section{KORESPONDENSI STRUKTUR KOGNITIF DAN STRUKTUR MASYARAKAT DALAM WORLDVIEW}

Telah ditunjukkan bahwa masyarakat memengaruhi praktik sosial secara langsung melalui struktur objektif dan tidak langsung melalui struktur kognitif. Bagian ini menunjukkan kerespondensi dua jenis struktur tersebut melalui konsep worldview. Istilah worldview mengacu pada beberapa pengertian. Worldview adalah skema implisit yang memungkinkan persepsi (Vaisey \& Lizardo, 2010). Istilah implisit sejajar dengan istilah virtual, karena worldview tidak terobservasi secara empiris dan bereksistensi dalam kognisi. Sementara itu, frasa "memungkinkan persepsi" berkaitan dengan peran worldview dalam proses berpikir dan bertindak, di mana worldview merupakan struktur yang berfungsi sebagai bingkai konseptual untuk memahami realitas dan memengaruhi kecenderungan dan tindakan agen (Bruning \& Lambe, 2009). Selanjutnya perlu ditegaskan bahwa worldview mengarahkan agen pada tindakan yang ada dalam batas-batas kultural masyarakat pembentuknya. Ini berarti worldview adalah struktur yang bersifat historis karena mengakar dalam konteks sosial (Demeter, 2012).

Pengertian ini mengandung sejumlah implikasi. Pertama, worldview bersifat paradigmatik karena berperan sebagai bingkai konseptual untuk memahami realitas dan memengaruhi tindakan sosial. Kedua, worldview adalah skema dalam kognisi yang bersifat kultural karena berakar dalam konteks sosial. Ketiga, karena worldview berakar dalam konteks sosial, pemahaman terhadap realitas senantiasa dimediasi oleh tradisi yang dihidupi agen dan tindakan yang dihasilkan hanya terjadi dan terpahami menurut konteks sosial tersebut.

Worldview adalah struktur kognisitif yang berakar pada konteks sosial di mana agen hidup, yang memengaruhi pemahaman terhadap realitas karena berperan sebagai paradigma, dan yang menstrukturkan kecenderungan maupun praktik sosial. Jadi, worldview memiliki pengertian yang sama dengan konsep struktur virtual-kultural-paradigmatis dalam perspektif Giddens. Namun berbeda dari Giddens, kosep worldview menekankan peran 
komponen-komponen kultural dalam pembentukan struktur kognitif. Komponen-komponen kultural merupakan "the most pervasive life-shaping perspective" (Wilkens \& Sanford, 2009), karena memengaruhi pembentukan worldview sebagai struktur yang bersifat vitual-kultural-paradigmatik dalam kognisi maupun regularisasi praktik sosial.

Hal ini dipahami melalui penjelasan Schultz dan Swezey (2013) tentang tiga dimensi-yang tidak terpisahkan dan yang berhubungan secara resiprokal-dalam worldview yakni: praanggapan-pranggapan yang diyakini begitu saja sebagai benar, praktik sosial teregularisasi sebagai eksternalisasinya, dan kecenderungan hati yang menentukan keyakinan dan perilaku. Status dan peran anggota masyarakat diatur berdasarkan prinsipprinsip narasi otoritatif komunitas, yang disosialisasikan significant others. Jika masyarakat meyakininya sebagai kebenaran, maka prinsip-prinsip tersosialisasi akan terinternalisasi menjadi skema pemahaman dalam kognisi (struktur kognitif). Melalui internalisasi prinsip-prinsip tersebut, struktur masyarakat masuk dalam kognisi anggotanya. Dalam situasi ini, prinsip-prinsip kultural menjadi praanggapan yang diyakini begitu saja sebagai benar dan yang berfungsi untuk memahami realitas (Schultz \& Swezey, 2013). Ini adalah petunjuk bahwa prinsip-prinsip yang disuarakan struktur masyarakat, melalui berbagai komponen kultural, telah masuk dalam kognisi dan membentuk skema kognitif, yang berkorespondensi dengan struktur masyarakat.

Contoh konkretnya adalah keyakinan jemaat protestan pascareformasi terhadap prinsip Alkitab yang menegaskan manusia sebagai gambar Allah, yang totalitas hidupnya merupakan ibadah kepada Allah. Keyakinan tersebut membentuk worldview baru, yang meniadakan dualisme sakral-sekuler. Kehidupan nongerejawi, yang pada Abad Pertengahan dianggap sekuler, dipahami sebagai ibadah yang sakral. Worldview yang terbentuk dari keyakinan terhadap narasi Alkitab menstrukturkan semangat, penilaian dan tindakan orang Kristen di setiap bidang hidup. 
Semangat atau etika ini diidentifikasi Weber dalam The Protestant Ethic and Spirit of Capitalism.

Internalisasi prinsip-prinsip kultural membentuk worldview, yang mengondisikan regularisasi praktik sosial yang bersesuaian dengan prinsip-prinsip dalam masyarakat dan diyakini begitu saja sebagai benar, bahkan menjamin rasa aman ontologis. Ini terjadi karena regularisasi tidak dapat dilepaskan dari usaha memperoleh dan menjamin rasa aman ontologis (Giddens, 1984), yang dapat dikaitkan dengan kestabilan sosial maupun dengan key life experience dan pemaknaan terhadap pengalaman hidup berdasarkan prinsip-prinsip narasi otoritatif.

Ini adalah petunjuk bahwa praanggapan-praanggapan yang terbentuk dalam kognisi-sebagaimana ditegaskan Schultz dan Swezey (2013)-mengarahkan kecenderungan untuk bertindak sesuai dengan prinsip-prinsip dalam struktur masyarakat dan kecenderungan tersebut hal ini tampak dalam praktik sosial. Worldview, yang terbentuk dari prinsip-prinsip terinternalisasi dan berkorespondensi dengan struktur masyarakat, merupakan konteks di mana key life experience dirasakan, pengalaman individual dimaknai, dan pemahaman terhadap realitas diperoleh. Secara natural dan spontan, prinsip-prinsip tersebut berfungsi dalam memahami realitas dan pengalaman dalam setiap dimensi hidup, sehingga kecenderungan hati dan praktik sosial dikondisikan olehnya. Key life experience yang diperoleh dengan menghidupi prinsip-prinsip kultural terinternalisasi akan memperkuat keyakinan terhadap berbagai praanggapan dalam narasi otoritatif dan memungkinkan regularisasi praktik sosial.

Jadi melalui internalisasi, komponen-komponen kultural dalam struktur masyarakat di luar manusia memasuki kesadaran dan membentuk worldview, yang mengondisikan regularisasi praktik sosial dan yang menjamin kestabilan masyarakat maupun rasa aman ontologis. Praktik sosial teregularisasi yang memberi rasa aman, makna hidup, dan hasil-hasil yang diharapkan membentuk kecenderungan untuk makin meyakini prinsip dan 
terus mengulangi perilaku. Relasi resiprokal ini membentuk sekaligus memperkuat struktur virtual dan kultural dalam kognisi.

Tekanan pada peran komponen-komponen kultural, yang mengandaikan eksistensi dan peran struktur masyarakat, dalam pembentukan worldview menegaskan perbedaan konsep worldview dari struktur virtual Giddens. Konsep worldview menunjukkan pengaruh struktur masyarakat, yang tidak kelihatan, melalui berbagai komponen kultural, terhadap regularisasi tindakan dan pembentukan struktur (yang ikut mengondisikan praktik sosial). Tindakan sosial merepresentasikan pengaruh struktur virtual maupun struktur masyarakat. Dengan demikian konsep worldview dapat memperlengkapi konsep struktur dengan menegaskan korespondensi struktur masyarakat dengan struktur virtual dalam kognisi anggota masyarakat.

Eksistensi worldview, sebagai struktur kognitif yang memiliki korelasi dengan struktur objektif dan yang menstrukturkan cara pikir dan tindakan memperkuat pengaruh kebudayaan terhadap masyarakat. Setiap keputusan, yang menentukan tindakan, tersituasi oleh worldview kultural. Jadi kepatuhan anggota masyarakat terhadap prinsip-prinsip yang terkandung dalam narasi otoritatif dan tadisi menjadi petunjuk pada eksistensi struktur objektif dan worldview dalam kognisi.

\section{SIMPULAN}

Teori strukturasi Giddens mengakui eksistensi struktur virtual dalam kognisi agen, yang terbentuk dari regularisasi praktik sosial dan mengonsidikan praktik sosial. Namun, Giddens menyangkali eksistensi dan peran struktur objektif, yang tampak dari melalui berbagai komponen kultural dalam masyarakat. Akibatnya, Giddens tidak dapat menjelaskan bagaimana praktik sosial pembentuk struktur kognitif dapat bereksistensi dan tergularisasi dalam masyarakat, sebelum struktur virtual terbentuk dalam kognisi agen. Dengan kata lain, Giddens tidak dapat menggunakan konsep struktur untuk menjelaskan asal usul praktik sosial teregularisasi, yang membentuk struktur kognitif. 
Tulisan ini melengkapi pemikiran Giddens tentang struktur dengan konsep worldview, yang menerima eksistensi struktur objektif-yang tidak kelihatan-namun menyatakan diri dan pengaruhnya melalui berbagai komponen kultural. Struktur objektif memengaruhi tindakan secara langsung melalui komponen-komponen kultural, dan secara tidak langsung melalui worldview yang terbentuk dari pengaruh komponen-komponen kultural. Konsep worldview menekankan korespondensi struktur masyarakat dan stuktur kognitif, yang memungkinkan tindakan yang bersesuaian dengan struktur objektif maupun tindakan yang berbeda, bahkan mengubah struktur. Konsep ini tidak hanya menjelaskan bagaimana masyarakat memengaruhi tindakan agen tapi juga menunjukkan hal-hal yang memungkinkan regularisasi praktik sosial, sebelum struktur kognitif terbentuk dan bagaimana hal itu terjadi. Melaluinya, pertanyaan yang tidak dapat dijelaskan secara memadai dengan konsep struktur-dalam teori strukturasimemperoleh penjelasan yang lebih baik.

Konsep worldview juga melengkapi konsep-konsep serupa, yang berguna dalam penelitian sosial. Konsep worldview menegaskan kaitan pengetahuan bersama-yang mengarahkan tindakan-dengan struktur sosial dan komponen kulturalnya, yang tidak diulas dengan jelas oleh Schutz dalam konsep appresentative structures. Konsep worldview juga mengaitkan pembentukan struktur sosial dan struktur kognitif dengan menekankan peran berbagai komponen kultural (sarana sosialisasi), sehingga dapat digunakan untuk melengkapi pemikiran Berger (yang tidak mengulas komponen-komponen kultural, yang menjadi sarana sosialisasi dan menjamin stabilitas) dan pemikiran Bourdieu (yang tidak menjelaskan peran struktur objektif dalam proses pembentukan struktur kognitif dan tindakan).

Selain itu, dengan menekankan dualitas struktur dan agen, konsep worldview mengatasi ketegangan dalam penjelasan tentang relasi struktur dan agen, yang mengandaikan dualisme (pemisahan), sebagaimana tampak dalam pemikiran Margaret Archer. Konsep worldview juga menekankan peran kapasitas 
reflektif dalam transformasi sosial, seperti yang dilakukan Ulrich Beck melalui konsep masyarakat resiko, yang menekankan peningkatan kapasitas reflektif subjek untuk mempertanyakan masyarakat, mencipta diri, dan mencipta bahkan mengubah masyarakat. Namun, konsep worldview menempatkan operasi kapasitas reflektif, untuk menghasilkan perubahan, dalam batasbatas kultural subjek. Dengan demikian, penekanan pada subjek ini dapat melengkapi pemikiran Habermas, yang menekankan tindakan komunikatif dalam dunia mikro, yang menjadi akar sistem sosial. Ia mengandaikan struktur dinamis yang terus berkembang, karena sistem sosial mengembangkan ciri strukturalnya, sehingga makin jauh dari kehidupan dunia dan memaksakan kotrol atas kehidupan dunia. Tetapi, konsep worldview mengaitkan perkembangan struktur dengan operasi akal agen.

Keunikan konsep worldview dapat dimanfaatkan sebagai bingkai konseptual untuk memahami fenomena sosial yang konkret, khususnya fenomena yang berkaitan dengan pengaruh struktur masyarakat terhadap praktik sosial (tradisi) dan pembentukan cara pikir (worldview) anggotanya. Penelitian dapat diarahkan untuk memahami bagaimana masyarakat menggunakan komponen-komponen kulturalnya untuk meregularisasi praktik sosial (seperti tradisi) dan bagaimana tradisi tersebut membentuk cara pikir (worldview) anggota masyarakat sehingga dapat teregularisasi dalam waktu yang panjang.

\section{DAFTAR PUSTAKA}

Berger, P., \& Luckmann, T. (1991). The social construction of reality: A Treatise in the Sociology of Knowledge. London: Penguin Books.

Bourdieu, Piere. (1996). The Rule of Art, Genesis and Structure of the Literary Field. Cambridge: Polity Press.

Bourdieu, Pierre. (1984). Distinction: A Social Critique of the Judgement of Taste. Cambridge, Mass.: Harvard University Press.

Bruning, S. D., \& Lambe, K. E. (2009). Linking worldview, relationship attitudes, and behavioral outcomes: Implications for the study and practice of public relations. Journal of 
242 Jurnal Filsafat, Vol. 31, No. 2, Agustus 2021

Promotion Management, 14(3-4), 139-151. https://doi.org/10.1080/10496490802620313

Demeter, T. (2012). "Weltanschauung" as a priori: sociology of knowledge from a 'romantic' stance. Studies in East European Thought, 64(1), 39-52. Retrieved from https://www.jstor.org/stable/41477748

Denscombe, M. (2014). The Good Research Guide: For Small-Scale Social

Research Projects (5th ed.). New York: Open University Press.

Dixon, K. (2011). A 'third way' for football fandom research: Anthony Giddens and Structuration Theory. Soccer $\mathcal{E}$ Society, 12(2), 279-298.

Giddens, A. (1976). New Rules of Sociological Method: A Positive Critique of Interpretative Sociologies (Second Edi). Cambridge: Polity Press.

Giddens, A. (1979). Central Problems in Social Theory: Action, structure and contradiction in social analysis. London: Macmillan Education LTD.

Giddens, A. (1984). The Constitution of Society: Outline of the Theory of Structuration. Cambridge: Polity Press.

Hoed, B. H. (2014). Semiotik dan Dinamika Sosial Budaya (3rd ed.). Depok: Komunitas Bambu.

Kamuri, J. P. (2020). Transformasi Wawasan Dunia Marapu: Tantangan Pembinaan Warga Gereja Di Sumba. Evangelikal: Jurnal Teologi Injili Dan Pembinaan Warga Jemaat, 4(2), 131-143.

Kamuri, J. P. (2021). Pandang Dunia: Penentu Kekuatan dan Perubahan Tradisi Masyarakat Tradisional. Paradigma: Jurnal Kajian Budaya, 11(1), 42-57.

Kamuri, J. P., \& Pratama, H. S. (2018). Autonomy and Historicity of an Individual as a Moral Agent. In M. Budianta, M. Budiman, A. Kusno, \& M. Moriyama (Eds.), Asia-Pacific Research in Social Sciences and Humanities (APRiSH) (pp. 37-41). Retrieved from https://library.oapen.org/bitstream/handle/20.500.12657/31061/ 639851.pdf? sequence $=1 \#$ page $=51$

Kassab, E. S. (1991). "Paramount reality" in Schutz and Gurwitsch. Human Studies: A Journal for Philosophy and the Social Sciences, 14, 
181-198. https://doi.org/https://doi.org/10.1007/BF02205602 Kinnvall, C., Manners, I., \& Mitzen, J. (2018). Introduction to 2018 special issue of European Security: "ontological (in)security in the European Union." European Security, 27(3), 249-265. https://doi.org/10.1080/09662839.2018.1497977

MacIntyre, A. (1984). After Virtue: A Study in Moral Theory (2nd ed.). Notre Dame, Indiana: University of Notre Dame Press.

MacIntyre, A. (2006). The Task of Philosophy. New York: Cambridge University Press.

Magnis-Suseno, Frans. (2000). Tokoh Etika Abad ke-20. Yogyakarta: Penerbit Kanisius.

Magnis-Suseno, Franz. (1992). Filsafat sebagai ilmu kritis. Yogyakarta: Penerbit Kanisus.

Schultz, K. G., \& Swezey, J. A. (2013). A Three-Dimensional Concept of Worldview. Journal of Research on Christian Education, 22(3), 227-243. https://doi.org/10.1080/10656219.2013.850612

Shani, G. (2017). Human Security as ontological security: a postcolonial approach. Postcolonial Studies, 20(3), 275-293.

Thoyyibah, I. (2015). Makna Kejahatan Struktural Korupsi Dalam Perspektif Teori Strukturasi Anthony Giddens. Jurnal Filsafat, 25(1), 134-171. https://doi.org/10.22146/jf.12617

Vaisey, S., \& Lizardo, O. (2010). Can Cultural Worldviews Influence Network Composition? Social Forces, 88(4), 1595-1618. Retrieved from https://www.jstor.org/stable/40645951

Van Rooyen, M. (2013). Structure and Agency in News Translation: An Application of Anthony Giddens' Structuration Theory. Southern African Linguistics and Applied Language Studies, 31(4), 495-506.

Wilkens, S., \& Sanford, M. L. (2009). Hidden Worldviews: Eight Cultural Stories that Shape Our Lives. Downers Grove, Illinois: IVP Academic. 